\title{
DEVELOPING GREETING AND SELF INTRODUCING MATERIALS DEALING WITH 2013 CURRICULUM OF THE SEVENTH GRADE IN MTsN BALANG-BALANG
}

\author{
Hikmawati \\ Universitas Negeri Makassar \\ hikmawati374@gmail.com \\ Djuwairiah Ahmad \\ Universitas Islam Negeri Alauddin Makassar \\ Djuwairiah.ahmad@uin-alauddin.ac.id
}

\begin{abstract}
Based on the preliminary study conducted in the MTsN Balang-Balang Gowa - Sulawesi, it is found that students demanded understandable materials to comprehend English subject as well as teachers faced several challenges in implementing the 2013 curriculum. In this regard, the complementary books are needed to complete the compulsory books provided by the government. Therefore, this study aims to develop a form of basic module and other references for teacher related to materials of greeting and self-introduction derived from 2013 curriculum. This study is Research and Development (R\&D) adapted from ADDIE Model (Analysis, Design, Development, Implementation, and Evaluation) by Steve J. McGriff, 2000. The research procedure will start from analyzing materials in the syllabus of the 2013 Curriculum, analyzing the students' need, designing the blueprint, developing the materials, implementing the materials in the classroom, and evaluating the materials by experts of 2013 Curriculum (evaluator students book) using experts' judgment and rubrics of analyzing student book set by National Standard. The result of experts' judgment and rubrics seems to be that the materials are good, well-designed, well-organized, and proper to use to the learners. It is also appropriate with the content of syllabus of the 2013 Curriculum and matches the students' need.
\end{abstract}

Keywords: Developing, Greeting and Self Introducing, 2013 curriculum, ADDIE Model.

\section{A. INTRODUCTION}

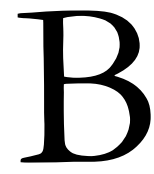

ased on the interview result on May 2015 with the English teacher at MTsN Balangbalang who reveal that there were still many obstacles faced by teachers in implementation of 2013 curriculum. First, the learning materials were not suitable with the students' understanding, because they did not covered student understanding needs. So, the students were not interested in learning process. Second, the teachers were not given authority to arrange the syllabus because it had been set by the National Standard. Third, the teachers indeed developed the learning planning process but the primary course book was limited. Next, the teacher claimed that the specialized training about the implementation of the 2013 curriculum 


\section{Hikmawati, Djuwairiah Ahmad, Developing Greetings and Self ...}

have not flattened yet. Finally, those caused the unpreparedness of the teachers to implement the materials on 2013 curriculum in teaching.

The first primary factor being one of the main obstacles is the lack of specialized training of religious ministries related to the implementation of the new curriculum. So that teachers were still ambiguous in understanding and applying the learning process based on 2013 curriculum as expected the government.

Second, interrupted by the lack of understanding of how to implement the applicable curriculum, teachers reveal that handbook was not enough to help them. Moreover, teaching materials based on the student and teacher handbook was not interesting to be applied.

After doing an interview, found that there are still many obstacles faced by teachers on implementing the 2013 curriculum in this school such as the unpreparedness of teachers in implementing the 2013 curriculum relating to the competence and creativity of teachers, the lack of specialized training of Religious Ministries related to the implementation of 2013 curriculum, facilities and learning resources (handbook) were inadequate and not enough to be applied. As the result, the teacher needed additional sources of teaching materials to vary the learning activities in the class based on 2013 curriculum effectively.

After identifying the problems and analyzing the factors above. Again, the teacher must have ability in developing teaching materials. On the study, the material development was both a field of study and a practical undertaking (Tomlinson, 2011). Then, the material could be developed from the authentic, video, text recording, and so forth that could cover student understanding needs. Besides, the lesson plan made of the English teacher was still lack of materials and activities. In addition, the lesson plan referred to the 3.14 .1 and 3.24 .2 competences need to be enriched many conversations especially for the greeting and selfintroducing materials. Therefore, complementary source become the problem solving of lack of capabilities in mastering conversations and skill items.

The best way to overcome inapplicable components on English teaching materials on the 2013 curriculum was to design English teaching materials in the form of textbook. In this case, developed English teaching materials based on the 3.1 and 4.1 also 3.2 and 4.2 competences that the writer formulated on a study entitled "Developing Greeting and Self Introducing materials dealing with 2013 Curriculum of the Seventh Grade in MTsN Balang-balang." For completing teacher text book appropriate with need student analysis.

\section{B. LITERATURE REVIEW}

Tegeh (2014) points out on his research "Pengembangan Bahan Ajar Seminar Problematika Teknologi Pendidikan Dengan ADDIE model" style this research is used system which has 


\section{Volume 3, Number 02, December 2017}

develop steps systematically and available to design and develop material deal with classic or individual. In addtition, ADDIE model is one of model in Research and Development method that appropriate for conduct this research.

Sukirman (Marshan, 2015) on his research "Developing English Morphology Course Material for Undergraduate Students" state that most students are not interest and motivated to learn English Morphology as one of the most difficult course and after identifying the problems and analyzing the factor. He design and develop English Morphology book as perfect as possible to build up students' motivation and stimulate them to be autonomous learners.

Mistahul Khair in his Research (Mubar, 2015) adopted ADDIE Model. ADDIE is acronym of Analysis, Design, Development, Implementation, and Evaluation.The result of the research showed that, the third grade students of MTsN Model Makassar want English materials especially speaking materials based on their needs. The existing materials that they used in learning still have many weaknesses. Then, these findings become the basic for the researcher to develop English learning materials especially for speaking.Finally, The English learning materials for students called speaking materials consist of six rules as main topic and 18 activities to improve students' speaking ability.

Thao Le \& Quynh Le (2006) The present study implies that Iranian EFL learners, due to their native language SCs, usually learn and tend to use only the polite forms of English greetings which may not necessarily be the least marked forms. Learners know they must choose language forms appropriate to a wide range of sociolinguistic variables. This may give them the feeling that, by choosing the polite forms, they refrain from making any great social blunder. However, this is not the case when the addressee is of a different age, sex, status, etc. This fact also holds true in multilingual contexts. The polite form might easily be judged as a sign of hostility or on-purpose distancing. The result will, no doubt, be what Thomas (1983) calls "pragmatic failure." Iranian EFL learners seem to violate social-appropriateness norms in ways that indicate a transfer of social norms from their native language. They also seem to fail to realize their speech acts effectively by either extending or over generalizing the potential illocutionary force of shared and non-shared strategies to inappropriate contexts or by failing to follow the usage conventions of the target language-in the realization of language-specific strategies. It, therefore, seems important that in the textbooks designed for Iranian EFL learners a part be included that concerns itself with this aspect of the English language.

Alessandro Duranti (2007) the analysis of greetings presented here shows that semantic analysis must be integrated with ethnographic information if we want to provide an adequate pragmatic analysis of speech activities within and across speech communities. Whatever greetings accomplish, they do it by virtue of the participants' ability to match routine expressions with 


\section{Hikmawati, Djuwairiah Ahmad, Developing Greetings and Self ...}

particular socio historical circumstances. To say that greetings are constituted by formulaic expressions maybe adapted to, and at the same time help establish, new contexts.

Alessandro has argued that we cannot compare greetings across speech communities unless we come up with a universal definition of what constitutes a greeting exchange. After proposing such a universal definition consisting of six criteria, Alessandro has shown that the tendency to see greetings as a devoid of propositional context or expressing "phatic communion" is too limiting and, in fact inaccurate. Greetings are, indeed, toward the formulaic end of the formulaiccreative continuum that runs across the full range of communicative acts through which humans manage their everyday life. But they can also communicate new information to participants through the types of questions they ask and kinds of answer they produce.

Based on the previous research above, concluded that, indeed, developing materials are needed to help students to understand easily and as the provided sources to practice English language skill particularly in enriching conversation abilities. It is also to create active learning situation around the students. In the implementation training handbook of 2013 curriculum competence was stated that lesson plan developed for the students learning principle actively through four activities. They are; 1) observing included seeing, reading, listening and heeding; 2) questioning included oral and written; 3) analyzing included connecting, determining, building the concept; and, 4) communicating included oral, written, picture, chart, table, presentation, and so forth.

\section{RESEARCH METHOD}

Based on the purpose of this study, the research design was Research and Development (R\&D). There were many models which can be applied by researchers such as Sugiyono model, ADDIE model, Borg \& Gall model, Dick and Carey model, Kemp model and many others. Based on many models stated previously, the researcher adopted ADDIE model because this model is very useful having stages clearly defined which makes implementation of instructions effectively. In addition, the model strives to save time and money by catching problems while they are still easy to fix.

The ADDIE model developed by Florida State University initially to explain, "...the processes involved in the formulation of an Instructional Systems Development (ISD) program for military inter service training that will adequately train individuals to do a particular job and which can also be applied to any inter service curriculum development activity." The model originally contained several steps under its five original phases (analyze, design, develop, implement, and evaluate). The idea was to complete each phase before moving to the next. Over the years, practitioners revised the steps, and eventually the model became more dynamic and 


\section{Volume 3, Number 02, December 2017}

interactive than the original hierarchical version. By the mid-1980s, the version familiar today appeared.

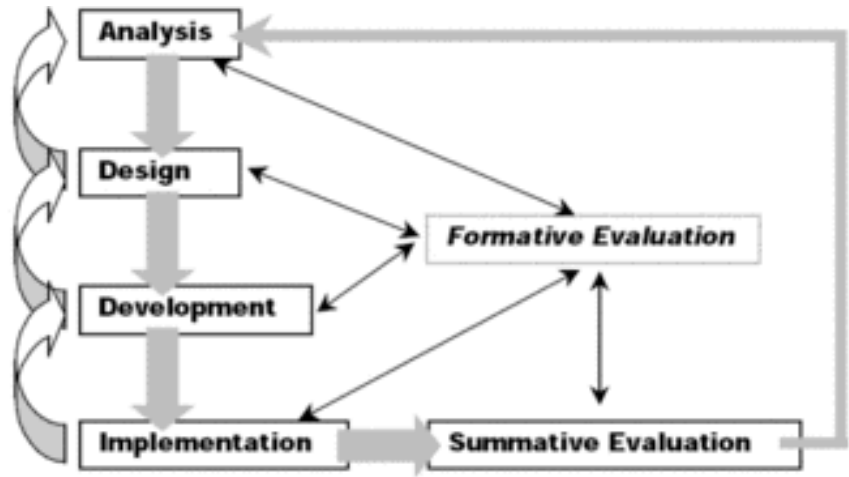

The ADDIE's Model (McGriff, 2000)

"ADDIE" that stands for Analyze, Design, Develop, Implement, and Evaluate is designed to ensure that the learners will achieve the goals and objectives of the learning purposes. It also provides simple procedure to design and develop materials. In addition, it is an iterative evaluation of each phase may lead the instructional designer back to any previous phase.

ADDIE model is designed to ensure that the learners will achieve the goals and objectives of the learning purposes. It also allows the evaluation of students' needs and provides simple procedure to design and develop materials.

\section{FINDINGS AND DISCUSSION}

\section{Findings}

The result of needs analysis based on the materials in the syllabus of 2013 Curriculum covering the $3.1,3.2,4.1$, and 4.2 competences were expected to the students to have both oral and written capacity of greeting and self-introducing materials appropriate with student's daily activities. Firts, the core topics had been designed into eight subtopics which were appropriate with the amount of meeting learnings. In other words, materials greeting and self-introducing materials were developed in several subtopics. Peculiarly in greeting material, occurred 2 subtopics; greeting and leaving-taking, thanking and apologizing.

Likewise, self introducing material consist of two subtopics also, there were; Self introduction and introducing the others. Second, every meeting had a core skill and it was integrated one another in flows of skill that the writer arranged sistematically. Again, learning activities dealt with scientific approach included observing, questioning, collecting information , associating, and communicating. Last, the writer developed learning instruction referring to the type of activities which was consisted of individu, pair, and group activitiy, the amount of 


\section{Hikmawati, Djuwairiah Ahmad, Developing Greetings and Self ...}

activities, text structure and some exercises. These materials were developed in order to provide suitable materials for the seventh grade students of MTsN Balang-Balang, Gowa.

Table 1

Systematic organization of material Aspect

\begin{tabular}{|l|l|l|l|l|l|l|}
\hline No. & Aspect & \multicolumn{5}{|c|}{ Form of material design } \\
\hline \multirow{3}{*}{$\begin{array}{l}\text { Systematic } \\
\text { organization } \\
\text { of material }\end{array}$} & $\begin{array}{l}\text { Real } \\
\text { Picture }\end{array}$ & $\begin{array}{l}\text { Black and } \\
\text { white }\end{array}$ & $\begin{array}{l}\text { Color } \\
\text { design }\end{array}$ & Cartoon & Video/Song \\
\cline { 3 - 7 } & Students & $\begin{array}{l}2 \\
\text { Students }\end{array}$ & $\begin{array}{l}20 \\
\text { Students }\end{array}$ & $\begin{array}{l}28 \\
\text { Students }\end{array}$ & 1 Student \\
\hline
\end{tabular}

Practically, in systematic organization of integrated English materials part, the writer found that all students wanted to be given the pre study orientation before studying. They are ice breaking, warming up, pray, motivation and inspiration story, small game, and all of it. It had been proved that all students chose YES and none chose NO. Therefore, the writer formulated the pre study orientation activities for implementing in the class and the students might choose three of them as the most favourite activity before studying so that the writer got the result showing 31 out of 36 students choosing ice breaking, 34 out of 36 choosing game and warming up, 12 out of 36 choosing pray, 9 out of 36 choosing motivation and inspiration story, and 3 out of 36 choosing all of it.

Next, it was found in data that 19 out of 36 students more liked listening the teacher's instruction than reading the instruction in the book which was only 6 chosen and no one liked to practice the instruction directly. 16 out of 36 students chose presentation as the learning material form, 10 out of 36 students chose dialog form, and 3 out of 36 students chose text form. In designing book, the students prefered picture book.

\section{Table 2}

Systematic English teaching which was appropriate with the learning Materials

\begin{tabular}{|l|l|l|l|l|l|l|}
\hline No. & Aspect & \multicolumn{5}{|c|}{ Activities } \\
\hline & Systematic & Pairs & Presentation & Grouping & Discussion & Individual \\
\cline { 3 - 7 } & learning & 9 & 16 students & $\begin{array}{l}30 \\
\text { students }\end{array}$ & $\begin{array}{l}16 \\
\text { students }\end{array}$ & $\begin{array}{l}6 \\
\text { students }\end{array}$ \\
\cline { 3 - 7 } & materials & students & & stud &
\end{tabular}

The result of systematic English teaching which was appropriate with the learning activities part had been obtained by the writer. The data showed that 9 out of 36 students chose to work in pair, 16 out of 36 students chose presentation, 30 out of 36 chose to learn with grouping and 6 out of 36 students chose to study individual. On the other hand, some students requested to study with playing game. 
Table 3

Systematic content of English materials

\begin{tabular}{|c|c|c|c|c|c|}
\hline \multicolumn{4}{|c|}{ No. Aspect } & \multicolumn{2}{|l|}{ Contents } \\
\hline & \multirow{3}{*}{$\begin{array}{l}\text { Systematic } \\
\text { content of } \\
\text { English } \\
\text { materials }\end{array}$} & \multicolumn{2}{|c|}{ Greeting material } & \multicolumn{2}{|l|}{ Self-Introduction } \\
\hline & & Formal & Informal & $\begin{array}{l}\text { Name, address, } \\
\text { hobby, idea }\end{array}$ & $\begin{array}{l}\text { Age, job, } \\
\text { closing }\end{array}$ \\
\hline & & 29 students & 7 students & 34 students & 27 students \\
\hline
\end{tabular}

As stead previously in the results of needs analysis, the systematic content of English materials covered the syllabus of the 2013 curriculum showed that 29 out of 36 students ordered formal material of greeting, 7 out of 36 students chose informal of greeting. 34 out of 31 students chose to add the content of self-introduction, such; name, address, hobby and idea. Meanwhile, 27 out of 36 students gave addition of contents are like; age, job and closing.

The result of product design included the blue print that covered every meeting, form of exercises, core skills, flow of skills, activities, text structures, Scientific approaches (observing, questioning, collecting information, associating, and communicating) topics and subtopics. They could not be separated from the analysis of the student needs.

Furthermore, this blue print included eight meetings with four subtopics. The topics of the first meeting until the fifth meeting was about greeting and leaving-taking, thanking and apologizing according to 3.1 and 4.1 competences. In the other hand, the topics of the sixth until eighth were about self-introduction and introducing others. In the greeting material, the author divided into two contents that were formal and informal greetings. Whilst, the sixth until the eighth meetings were about self-introduction and introducing others, each of the meetings has different content of materials for example the first meeting was the greeting expressions and generic structures. Withal, the author defined core and flow skills in every meeting with an explanation of each activity groove skill changes. In one meeting, the author also complemented teaching materials with exercises and generic structure.

Usually there were two or more exercises into one approach. For example at the first meeting, discussed subtopic greeting expressions on stage exactly there were two exercises. The first exercise students were asked to follow the pronunciation of the teacher. Then the students asked to repeat the types of greeting expression that she had learned. But not always be required 


\section{Hikmawati, Djuwairiah Ahmad, Developing Greetings and Self ...}

to exercise at every approach, as in the first meeting no exercise at the stage of questioning. But in other approaches such as collecting information, associating and communicating are exercises.

By this terms, the author developed cover design, layout, organization of materials, and instructional objectives.

\section{Cover design}

The author created the cover with simply and meaningful. Therefore, the cover of this instructional material was attractive to the learners.

2. Layout

The author rearranged the layout of some components of instructional material. Hence, the layout looked clear for learners.

\section{Organization of materials}

The author formulated to the materials organized attractively, appropriate with real picture, color design, and cartoon. Moreover, the materials are organized in logically ordered tasks.

4. Instructional objectives

By the material design and research purposes, the author formulated the instructional objectives are clear, understandable, appropriately. Furthermore, also the instructional objectives reflect to the topic.

\section{Systematic English teaching}

In simple terms, the author developed form of the instructional materials such as activities, examples, topics and subtopics.

1. Activities; the activities were attractive, motivated learners and varied in format.

2. Example; the Examples are clear, understandable, too easy. In addition, the example helped learners to understand the material.

Systematic content of English materials

Dealing with material design (blue print), the author formulated the topic/ subtopics, content of materials, and language.

The content of the materials were clear, and understandable. Besides that, the content of the materials matched the objectives of the course. The contents of the materials were matched with the curriculum 2013, and students' needs. Also, the contents were interesting, well-designed, and up-to-date.

Systematic Language of English materials

The language was used appropriate with students' English proficiency. Thereupon, the language was clear and understandable.

Expert judgment suggestion 


\section{Volume 3, Number 02, December 2017}

Considering of the teaching materials that developed, the expert found some grammatical errors and misspelling words in the product, especially in instruction of scientific approaches. The expert also told the author to use the simple language in the content of materials. Forward, the expert said that the author should implement the material immediately.

Therefore, All of the results were discussed on the following weighted achievement by an observer with the 1 until 4 grading scale, with the meaning; 1 (very good) 2 (good) 3 (less good) 4 (not good). The results of the observer ratings, the first was a form motivation of students that include; associate learning materials were now with the experience of learners (score 4). Asking challenging questions (score 3). Delivering the benefits of learning materials (score 3). Demonstrating something related to the subject matter or theme (score 4) and checking the behavior of the initial (entry behavior) (score 3). The second was the delivering of competency and plan activities that include; delivering the capability to be achieved learners (interaction KI 3 and KI 4 which have implications for the development of KI 1 and KI 2) (score 4) and submitting an action plan (score 3).

Furthermore, the core learning phase to consider several aspects including; mastering of the material which cover; the ability to adapt material to the learning objectives (score 4). The ability to link the materials with other relevant knowledge, science, and technology development and real life, (score 3), managing the discussion of learning materials with learning experiences appropriately (score 4). Presenting material in a systematic (easy to difficult and concrete to the abstract) (score 4).

\section{Discussions}

As indicated by the result of the questionnaire and interview with the teacher in MTsN Balang-balang that there were still many obstacles faced by teachers in implementation of 2013 curriculum. First, the systematic contents of materials were not suitable with the students' understanding, because they did not cover student understanding needs. It was not clear and confusing. So, the students were not interested in learning process. Second, the systematic learning material were not varies, no ways to minimize the students' boredom. Third, the teachers indeed developed the learning planning process but the primary course book was limited. Fourth, although there are already several schools but the student handbook is still difficult to be implemented by teachers due to the uneven implementation of the training curriculum in 2013, particularly in MTsN Balang-balang. In addition, the systematic organization of the material in the K13 handbook needed to be developed according to student needs.

Based on the research focus presented in the previous chapter, there was a research question by covering 3 subtopics questions that will be answered. They were systematic organization of materials, systematic content of materials and systematic learning of materials. 


\section{Hikmawati, Djuwairiah Ahmad, Developing Greetings and Self ...}

Accordingly, the researcher tried to develop the teaching materials which according to student needs and based on 2013 Curriculum systematic by using ADDIE Model.

The findings above are in line with some previous research findings. First, Tegeh (2014) points out on his research "Pengembangan Bahan Ajar Seminar Problematika Teknologi Pendidikan Dengan ADDIE model" style this research is used system which has develop steps systematically and available to design and develop material deal with classic or individual. In addtition, ADDIE model is one of model in Research and Development method that appropriate for conduct this research.

Second, Sukirman (2012) on his research "Developing English Morphology Course Material for Undergraduate Students" state that most students are not interest and motivated to learn English Morphology as one of the most difficult course and after identifying the problems and analyzing the factor. He design and develop English Morphology book as perfect as possible to build up students' motivation and stimulate them to be autonomous learners.

Moreover, in the terms of the frequency of student needs of questionnaire questions, the researcher indicated that in learning English, particularly in learning Greeting and Self Introducing materials, students needed materials was well-organized, understandable, easy to be understood, full color, real pictures, song/video and dealt with syllabus of the 2013 Curriculum.

Tomlinson (2011: 2) defines that materials refers to the anything which is used by teachers or learners to facilitate the learning of a language. Materials could absolutely be videos, DVDs, emails, Youtube, dictionaries, grammar books, readers, workbook or photocopied exercises. In addition, they could also be newspaper, food packages, photographs, live talks by invited native speakers, instruction given by teacher, task written on cards or discussion between learners. However, language-learning materials are not only course book but many things because that has been the main experience by using materials.

Furthermore, for the research question about need analysis, the researcher found that was in systematic organization of materials, the students need to learn with full color, real picture, cartoon, and video /song. In other hand, the researcher found that learning process / activities should be considered in teaching and learning process, the findings obtained from the students show that study in small group, presentation, work in pair, discussion, and self-study/individual are preferred by the students. But among them the students rate study in small group in mean score higher than the others.

Moreover, the result of analysis from the result of evaluation of Student's Book Analysis Instrument by the expert, were well-defined goals. In addition, the results of analysis from the result of evaluation showed that the learning activities/tasks were varied in format. For instance, practice the useful expression, discussions, pairs, small group, presentation and individual. Surely, 


\section{Volume 3, Number 02, December 2017}

the results of teaching materials from the result of validation showed that goals of product design were clear and understandable.

\section{E. CONCLUSION}

Based on the result of the data analysis, research findings, and discussion in the previous chapter, the researcher concluded that:

1. The systematic organization of integrated greeting and self-introducing materials based on the 2013 Curriculum.

2. The systematic English Teaching which is appropriate with the learning activities based on the 2013 Curriculum.

3. The systematic content of greeting and self-introducing materials covered the syllabus of the 2013 Curriculum.

\section{REFERENCES}

"ADDIE Model". Instructional Systems, College of Education, Penn State, University.http://www.instructionaldesigncentral.com/htm/IDC instructionaldesignmodels htm\#addie. (May 2015)

Adilah, Naila. (2013). Analysis of curriculum 2013 implemented at seven grade of smp 2 bandarlampung. Journal (Online)

Arikunto, Suharsimi. (2013) Prosedur Penelitian. Jakarta: Rineka Cipta.

Badruddin, D. (2015). DEVELOPING A TASK-BASED SYLLABUS BASED ON NEEDS ANALYSIS FOR MIDWIFERY AT UIN ALAUDDIN MAKASSAR. ETERNAL (English, Teaching, Learning, and Research Journal), 1(1), 112-130.

Haryati, M. (2008) Model dan Teknik Penilaian pada Tingkat Satuan Pendidikan. Jakarta: Gaung Persada Press. Hlm. 1.

Kemendikbud. (2014). Modul Pelatihan Implementasi Kurikulum 2013. Jakarta: Badan Pengembangan Sumber Daya Manusia dan Kebudayaan

Khoir, Miftahul. (2015) "Developing English Learning Materials for Young Learners Based on Needs Analysis," Thesis. Makassar: School of Graduate Studies, State Islamic University of Alauddin.

Kurniawan, A. (2015). THE IMPLEMENTATION OF THE 2013 CURRICULUM IN LEARNING ACTIVITIES CONDUCTED BY THE ENGLISH TEACHER OF FIRST GRADE AT JUNIOR HIGH SCHOOL 17 MAKASSAR. ETERNAL (English, Teaching, Learning, and Research Journal), 1(1), 131-144.

Mahirah, R., Ahmad, D., \& others. (2016). DESIGNING MULTIPLE CHOICE TEST OF VOCABULARY FOR THE FIRST SEMESTER STUDENTS AT ENGLISH 


\section{Hikmawati, Djuwairiah Ahmad, Developing Greetings and Self ...}

EDUCATION DEPARTMENT OF ALAUDDIN STATE ISLAMIC UNIVERSITY OF MAKASSAR. ETERNAL (English, Teaching, Learning, and Research Journal), 2(2), 194-208.

Marshan, S. (2015). Developing English Morphology Materials For Undergraduate Students At Alauddin State Islamic University Of Makassar. ETERNAL (English, Teaching, Learning, and Research Journal), 1(1), 1-14.

Mubar, M. K. N. A. (2015). Developing English Learning Materials For Young Learners Based On Needs Analysis At Mtsn Model Makassar. ETERNAL (English, Teaching, Learning, and Research Journal), 1(2), 313-330.

Mulyasa, E. (2013). Pengembangan dan Implementasi Kurikulum 2013: Perubahan dan Pengembangan Kurikulum 2013 Merupakan Persoalan Penting dan Genting. hlm. 65.

Nation \& Macalister.(2009) . Language Design Curriculum. Taylor \& Francis e-Library.

Ningsih, A. A., \& others. (2016). Designing Crossword Puzzle To Improve Students'vocabulary Mastery Of The Third Semester In English Education Department Student Of Uin Alauddin Makassar. ETERNAL (English, Teaching, Learning, and Research Journal), 2(1), 37-54.

Nurpahmi, S. (2013). An Introduction to English for Specific Purposes. Makassar: Alauddin University Press.

Nurpahmi, S. (2014). English for Specific Purposes: An Integrated Approach. Makassar: Alauddin University Press.

Nurpahmi, S. (2017). ESP Course Design: An Integrated Approach. Lentera Pendidikan: Jurnal Ilmu Tarbiyah Dan Keguruan, 19(2), 172-181.

Poerwati. Endah, L. \& Amri, S.( 2013). Panduan Memahami Kurikulum. Jakarta: PT. Prestasi Putra Karya.

Pratt, B.(1980). Curriculum Design and Development. New York: Harcourt Brace Javanovich Publishers. Hlm. 4.

Richard, Jack C.(2007) Curriculum Development in Language Teaching. New York: Cambridge University Press.

Sukirman.(2015). Developing English Word formation materials for undergraduate students at State Islamic University “Alauddin” Makassar. Jurnal Eternal Volume 1 Number 1.Alauddin University Press.

Sukirman.(2013). Developing English Word formation materials for undergraduate students at State Islamic University "Alauddin" Makassar. Unpublished Thesis of the Degree of Master of English Language Teaching. Malang: State University of Malang.

Tegeh, I Made dkk. (2014) Model Penelitian Pengembangan. Singaraja: Graha Ilmu.

Thomas, David R.(2006) A General Inductive Approach for Analyzing Qualitative Evaluation Data. New Zealand: University of Auckland. 